International Journal of Social Science and Economic Research

ISSN: 2455-8834

Volume:05, Issue:09 "September 2020"

\title{
UNIFORM CIVIL CODE AND DEFENCE OF SHAH BANO JUDGEMENT
}

\author{
Yuvraj \\ PhD. Research Scholar, School of Social Sciences ,Amity University \\ DOI: 10.46609/IJSSER.2020.v05i09.024 URL: https://doi.org/10.46609/IJSSER.2020.v05i09.024
}

\begin{abstract}
Uniform Civil Code (UCC), in itself is like an 'always getting edited' version of itself. No matter how deep or extensive commentaries or debates we allow in favour or against it, it never seems to solemnize into a proper law. Maybe India, as a nation, or state, can accommodate it in the parliament or courts' judgements but in the view of executive and legislative application, the aspect of UCC fails to get acknowledged, or we can even say that, it does not receive the attention it should.

Anyhow, as the diversity, a factor, well debated in India's struggles in not getting on an impartial and for-all well-being platform, or say egalitarian perspective is one of the reasons that, legislature have not been able to procure a sound unified code of bill alike UCC for the Indianized idea of personal laws.

It somehow makes it appear realistic that, diversity and personal laws manifested in the Indian culture, and sense of belongingness, are something like a, 'superficial illustrations of traditions and religions which are being run in parallel with the idea of being a 'different' from one another. Be it in case of marriage, dowry, polygamy or polyandry, child marriage or divorce etc., each of the religious manifestations of laws codified as personal laws, gives an appearance of scratched boundary carved down for people belonging to that particular religion.

So, in this paper which is formalized as of a debate between the Uniform Civil Code and the Muslim religion scepticism of being a minority in India, with special emphasis on female as a gender in subjugation within the ambit of personal law applicability would be testified. In this paper, I would be evaluating Muslim personal laws applicability by evaluating through a case law: Mohd. Ahmed Khan vs Shah Bano Begum and Ors on 23 April, 1985, with respect to how and why it raises the need for the Uniform Civil Code Idea.

Stating this we would put forward that, as the paper will progresses, the idea would be to understand, how Muslim personal law is in contradiction with the idea of UCC and how far has its implications been stretched. And this would be done keeping in perspective the case law mentioned above.
\end{abstract}


International Journal of Social Science and Economic Research

ISSN: 2455-8834

Volume:05, Issue:09 "September 2020"

The process followed would be of discussing the literature which would point out the meaning and context of both UCC and Muslim Personal Law.

Thereafter, some significant amount of time and space for understanding would be devoted on the case study for better grasping of the aspects in focus and with a practical and theoretical perspective.

\section{INTRODUCTION}

In order to begin on a note of understanding of what is UCC and what are the personal laws of Muslims is what we are going to be talking here; it would be appropriate to first define certain terms in accordance with their origin and practice in the nation.

\section{WHAT IS UCC?}

UCC or Uniform Civil Code debate of what it is dates back 1853, in the Second Law Commission report of India. There and then also the concept of UCC was discussed vividly. I would here like to present some of the points, of which I consider as crucial in understanding of the concept of UCC from the Law Commission report itself. But before we step into the contextual or more elaborative format of understanding UCC, it would be just to mention what actually UCC is from the version of understanding it through the lens of generalized perspective

UCC is a concept of secular law as common to all citizens of India, irrespective of their caste, gender or specifically religion. It is a form of rules or set of rules to be applicable as a set of ideals equally for all religions that form the part of Indian state. The nature and concept of UCC are both in different contexts justified. Where on one hand we do not have UCC as a law enacted within the Indian territory for its people, the debate upon the need for UCC is stemming from the Constituent Assembly debates and as debated by the Chairman of the Drafting Committee, Dr. B.R. Ambedkar:

On December 2, 1948, Dr. B.R. Ambedkar, seen as one of the architects of the Constitution, defended the state's endeavour to put in place a uniform civil code in future by including it among the Directive Principles of State Policy.

But this couldn't be done by force, he told the Constituent Assembly, adding that it would be "mad" to introduce it by "provoking Muslims." This was days after he had suggested, on November 23, 1948, that the future Parliament could

— for a start — extend it to those who voluntarily agreed to be bound by it. ${ }^{1}$

So far, we have discussed the fragmented definition of UCC or what implications it holds or held 


\section{International Journal of Social Science and Economic Research}

ISSN: $2455-8834$

Volume:05, Issue:09 "September 2020"

in the past. But if we go by the constitutional mandate of understanding the UCC, it would become easier to grasp the concept in much objective manner:

The idea of the Uniform Civil Code comes from Article 44 of the Indian Constitution where it is enshrined under Part IV i.e. the Directive Principles of State Policy. It is been recommended that state shall strive to bring into force a Uniform Civil Code which would govern all the religions and communities, and will even be followed as a centralised law for or against different personal laws of every community/religion vesting in India.

This shows the vision and need of having a Uniform Civil Code for a democratic country like India where it was even enshrined as an ideal in the constitution. It was even then and it is even now felt as a need of the hour to accommodate the diversity question of India.

The way it is there, as one of the directive principle(s), it is pretty much clear that it is not justiciable, since not being a Fundamental Right. But it is also pretty much clear that to answer the multiple contradictions of multiple personal laws and their adjudication, accommodating the minority existence questions.

More over the facts that these personal laws not only exist to personal benefits of the elite preachers and clergy amongst the community, but are also a source of contradictions to certain activities, such as child marriage, dowry and polygamy or marriage in itself, such are far more critical questions to be taken into account for the revolutionizing of the Indian society and implying UCC,than just simply and forcibly one day making a statement for all Indians to be covered under the umbrella of Uniform Civil Code.

Now, as we have made a broader layout of what is UCC, coming back to the theme of the paper of contrasting UCC with Muslim personal law; we would now have to take into account the standard understanding of: what are personal laws and why and how is Muslim Personal Law a contradiction? Especially in matters where women rights are concerned. This part of the paper we would deal with case law like Shah Bano.

\section{WHAT IS PERSONAL LAW?}

Bringing the discussion to streamline process of what actually are personal laws? And how and what are its effect on society and people governed under it?

So basically, Personal Laws are the laws which governs an individual in personal matters within and according to religious statecraft. We have laws in relation to Hindus (which include Sikhs, Buddhists, and Jains), Muslims, Christians and Parsis. These laws were made and implied upon 


\section{International Journal of Social Science and Economic Research}

ISSN: $2455-8834$

Volume:05, Issue:09 "September 2020"

an individual by birth in a particular and specific religion, keeping in mind the way the customs followed in the respective religion.

Under Hindu Law, one has the Hindu Marriage Act, 1955, The Hindu Succession Act 1956, the Hindu Minority and Guardianship Act, 1956 and the Hindu Adoption and Maintenance Act 1956. These are the personal laws for Hindus. The Hindu Law is applicable to Jains, Buddhists and Sikhs.

For Muslims, The Muslim Personal Law (Shariat) Application Act, 1937 is one of the main acts which deals with marriage, succession, inheritance and charities among Muslims. The Dissolution of Muslim Marriages Act, 1939 deals with the circumstances in which Muslim women can obtain divorce and The Muslim Women (Protection of Rights on Divorce) Act, 1986 deals withthe rights of Muslim women.

Christians are governed by the Indian Christian Marriage Act 1872. This is applicable to all Indian Christians except in Goa as they have their own personal code.

Parsis are governed by the Parsi Marriage and Divorce Act (1936).

Here where our main concern is related to Muslim Personal Law, it should be explicitly revealed in this paper, so for the purpose of the same, I would here like propose and state: The Muslim Personal Law (Shariat) Application Act, 1937:

\section{The Muslim Personal Law (Shariat) Application Act, 1937}

1. Short title and extent:

- This Act may be called the Muslim Personal Law (Shariat) Application Act, 1937.

- It extends to the whole of India [except the State of Jammu and Kashmir]

2. Application of Personal law to Muslims. - Notwithstanding any custom or usage to the contrary, in all questions (save questions relating to agricultural land) regarding intestate succession, special property of females, including personal property inherited or obtained under contract or gift or any other provision of Personal Law, marriage, dissolution of marriage, including talaq, ila, zihar, lian, khula and mubaraat, maintenance, dower, guardianship, gifts, trusts and trust properties, and wakfs (other than charities and charitable institutions and charitable and religious endowments) the rule of decision in cases where the parties are Muslims shall be the Muslim Personal Law (Shariat). 


\section{International Journal of Social Science and Economic Research}

ISSN: $2455-8834$

Volume:05, Issue:09 "September 2020"

3. Power to make a declaration:

- Any person who satisfies the prescribed authority:

- that he is a Muslim; and

- that he is competent to contract within the meaning of section 11 of the Indian Contract Act, 1872 (9 of 1872); and

- that he is a resident of [the territories to which this Act extends], may by declaration in the prescribed form and filed before the prescribed authority declare that he desires to obtain the benefit of [the provisions of this section], and thereafter the provisions of section 2 shall apply to the declarant and all his minor children and their descendants as if in addition to the matters enumerated therein adoption, wills and legacies were also specified.

Where the prescribed authority refuses to accept a declaration under sub- section (1), the person desiring to make the same may appeal to such officer as the State Government may, by general or special order, appoint in this behalf, and such office may, if he is satisfied that the appellant is entitled to make the declaration, order the prescribed authority to accept the same.

Rule-making power:

- The State Government may make rules to carry into effect the purposes of this Act.

- In particular and without prejudice to the generality of the foregoing powers, such rules may provide for all or any of the following matters, namely:

for prescribing the authority before whom and the form in which declarations under this Act shall be made;

1. for prescribing the fees to be paid for the filing of declarations and for the attendance at private residences of any person in the discharge of his duties under this Act; and for prescribing the times at which such fees shall be payable and the manner in which they shall be levied.

2. Rules made under the provisions of this section shall be published, in the Official Gazette and shall thereupon have effect as if enacted in this Act.

3. Every rule made by the State Government under this Act shall be laid, as soon as it is 
International Journal of Social Science and Economic Research

ISSN: 2455-8834

Volume:05, Issue:09 "September 2020"

made, before the State Legislature.]

4. Dissolution of marriage by Court in certain circumstances.

Repeals: [The undermentioned provisions] of the Acts and Regulations mentioned below shall be repealed in so far as they are inconsistent with the provisions of this Act, namely:

1. Section 26 of the Bombay Regulation IV of 1827 ;

2. Section 16 of the Madras Civil Courts Act, 1873 (3 of 1873);

3. Section 3 of the Oudh Laws Act, 1876 (18 of 1876);

4. Section 5 of the Punjab Laws Act, 1872 (4 of 1872);

5. Section 5 of the Central Provinces Laws Act, 1875 (20 of 1875); and

6. Section 4 of the Ajmer Laws Regulation, 1877 (Reg. 3 of 1877). ${ }^{2}$

Now since we have an elucidated version of how and what is Muslim personal law, I would here like to bring into the factorized version and purpose of writing this paper.

Primarily this paper is being written with the intention of providing a justified opinion on the question of gender justice, the Muslim Personal Law could have done or does in any form or not?

This perspective of gender justice will be vehemently dealt in concern with the case study which happened in the past in the Indian democracy, and was an eye opener for the all the three branches of the government and society as a whole.

\section{SHAH BANO CASE:}

Shah Bano, a divorced Indian Muslim woman who took her husband to court to sue for maintenance. Shah Bano, who was in her sixties, had been

married to her husband for over forty years at the time of the divorce. In 1979 she was awarded Rs. 25 per month as maintenance, under section 125 of the Criminal Procedure Code of India. She appealed this award to the High Court of Madhya Pradesh, which increased her award to Rs. 179.20 per month. 


\section{International Journal of Social Science and Economic Research}

ISSN: $2455-8834$

Volume:05, Issue:09 "September 2020"

Her husband, an advocate by profession, appealed against the order of maintenance to the Supreme Court of India, arguing that the order for maintenance conflicted with Muslim personal law. He argued that, since he had already fulfilled his obligation to Shah Bano under Muslim personal law, he could not be ordered to pay her any further maintenance.

The Muslim Personal Law Board, an organization known for its traditionalist leanings, intervened in the case on behalf of the husband. In April 1985, after a ten-year legal battle, the Supreme Court upheld the order for maintenance and dismissed the husband's appeal. ${ }^{3}$

The Muslim Personal Law Board and other Muslim fundamentalist groups began to organize demonstrations against the decision. Muslims, both men and women, gathered in the thousands to protest against the Supreme Court judgement. In October 1985, more than four hundred thousand Muslims gathered to attend a conference on Muslim personal law. In November 1985, in Bombay, more than three hundred thousand Muslims joined a protest march against the judgement. The agitation that followed the Shah Bano judgement

was the biggest one launched by Muslims in the post-independence period. The fundamentalist groups that organized the demonstrations demanded that the government enact legislation that would exempt Muslims from the provisions of section.

So, as we can see this case was the eye opener for the Indian Judiciary and was screamingly deceptive version of what worst could happen if UCC will not be brought into the picture soon. Shah Bano case, was one such forepoint factor which described the atrocity of a Muslim women and her rights in the society. Not only this, it even brings out the version of personal laws to be extensive to that extent that it could create an immoral and deceit kind of feeling against the female gender which belongs to the minority or religious minority (to be specific).

\section{The Muslim critique ofthe judgment focused on four distinctive but interrelated points:}

1. The interpretation by the Supreme Court of Section 125 of the Criminal Procedure Code;

2. The Court's interpretation of certain verses of the Quran;

3. The Court's allegedly disparaging remarks about the degradation of women in Islam and the Muslim husband's unfettered right of divorce; and

4. The obiter dictum of the judgment recommending a speedy promulgation of a uniform civil code. ${ }^{4}$ 
International Journal of Social Science and Economic Research

ISSN: 2455-8834

Volume:05, Issue:09 "September 2020"

\section{CONCLUSION}

If Muslim countries can reform Muslim Personal Law, and if western democracies have fully secular systems, then why are Indian Muslims living under laws passed in the 1930s?

The real social opposition each time has come from the Muslim community that sees any attempt to bring a UCC as an attack on its religious rights.

The debate in India seems to have gone the way beyond the secularists in this respect and the recent rulings by the Supreme Court calling for a Uniform Code have not witnessed the protests and alarms that took place following the Shah Bano case in 1985.

It is quite possible that the Muslim community sees a Uniform code as a fait accompli after almost 60 years of Indian independence. The matter is far more political than legal. Every time the issue has come up there have been angry words from both sides of the debate.

Religious fundamentalism must go, social and economic justice must be made available to the Muslim women and other women and their dignity and quality be ensured, basic human rights guaranteed and there should be an end to exploitation of Muslim women ${ }^{5}$

So far as we have come in this essay, it is for sure that no extraordinary literature I have either quoted, or tried to put into the paper as, I believe for an independent opinion for the problem we are trying to counter and bring out a, needless to say, neutral opinion on the same.

When the first class of feminism as an ideology was taught to me, way back in 2013, the educator made a statement stating: 'personal is political'. I got truly intrigued by the line and formulated my entire philosophy regarding women's concern directed in the same way.

Be it romanticism or domestic violence, we could very easily relate these factors with what personal laws of religious communities have done for the gender justice. Taking my another set of opinion from Shah Bano case, where it was quite a learning experience in order and way how a woman strives against the time tide of patriarchal model of society and how she brings out the Judiciary to be on the verge of collapse in stating and defining laws which were applied to/in the Shah Bano case to bring out a constitutional solution to the issue of alimony and triple talaq in Muslim religion.

I would like to state that, though personal laws are one such factor which have been on the spike in the diversified Indian democracy. But the time and tide are in the direction where the need is 
for a more diversified and above the ground level law like Uniform Civil Code, which could bring the entire Indian society under one umbrella of equality and fraternity. The laws of UCC would be so that the questions of gender, violence, talaq, marriage or divorce, child marriage etc., would be easily handled with and thus a unanimity could be justifiably brought in.

\section{References}

1. Vikas Pathak, 'Ambedkar favoured common civil law' The Hindu (December 01, 2015)

2. https://indiankanoon.org/doc/1325952/; 18 May, 2020

3 . Nawaz Mody, "The Press in India: The Shah Bano Judgement and its Aftermath," Asian Survey vol. XXVII, no. 8 (August 1987): 935-936; 7akia Pathak and Rajeswari Sunder Rajan, "Shah Bano,"in

Signs: Journal of Women and Culture vol.14, no.3 (Spring 1989): 559-587.

4. Nawaz B. Mody, 'The Shah Bano Judgment and Its Aftermath' http://www.jstor.org/stable/2644865

5. https://poseidon01.ssrn.com/ 